임신 중 증상 발현한 담관낭종을 내시경 초음파 유도 담도 배액술로 치료한 1예

울산대학교 의과대학 서울아산병원 ${ }^{1}$ 내과, ${ }^{2}$ 병리과, ${ }^{3}$ 소화기내과

이경민 ${ }^{1} \cdot$ 강지은 $^{1} \cdot$ 이형경 ${ }^{1} \cdot$ 안소연 $^{2} \cdot$ 홍승모 $^{2} \cdot$ 이현우 $^{3} \cdot$ 박도현 $^{3} \cdot$ 김명환 $^{3}$

\title{
Symptomatic Choledochal Cyst in Association with Pregnancy Managed with EUS-guided Choledochoduodenostomy without Fluoroscopic Guidance
}

Kyoung Min Lee', Ji-Eun Kang', Hyeung Kyeung Lee', Soyeon An², Seung-Mo Hong ${ }^{2}$, Hyun Woo Lee ${ }^{3}$, Do Hyun Park ${ }^{3}$, Myung-Hwan $\mathrm{Kim}^{3}$

Departments of IInternal Medicine, ${ }^{2}$ Patology, ${ }^{3}$ Divison of Gastroenterology, Asan Medical Center, University of Ulsan College of Medicine, Seoul, Korea

Choledochal cyst has only rarely been encountered in association with pregnancy. The clinical manifestations are nonspecific and variable that makes it difficult to differentiate from physiologic changes in pregnancy. Consequently, diagnosis is often delayed until patients present with life-threatening complications. During pregnancy, symptoms of choledochal cyst may be developed by hormonal changes and the enlarged uterus. Because of the risk of fetal mortality and maternal morbidity, definitive surgical treatment should be delayed and step-by-step management should be carefully implemented to avoid complication until delivery. Herein, we report a case of enlarged, symptomatic choledochal cyst that developed in a 26-year-old pregnant woman. The temporal relationship between pregnancy and symptom development, as well as the biliary sludge formation in the enlarged cyst, suggest that the choledochal cyst was influenced by pregnancy. In order to buy time for fetal maturation, endoscopic ultrasonography-guided choledochoduodenostomy was performed for biliary decompression as a bridge to surgical excision.

Korean J Pancreas Biliary Tract 2017;22(2):92-97

Keywords: Choledochal cyst, Pregnancy, Endoscopic ultrasonography, Choledochoduodenostomy

\begin{abstract}
Received Feb. 5, 2017
Revised Mar. 1, 2017

Accepted Mar. 7, 2017
\end{abstract}

Corresponding author: Myung-Hwan Kim Division of Gastroenterology, Asan Medical Center, University of Ulsan College of Medicine, 88 Olympicro 43-gil, Songpa-gu, Seoul 05505, Korea Tel. +82-2-3010-3183 Fax. +82-2-485-5782 E-mail; mhkim@amc.seoul.kr 


\section{서 론}

담관낭종(choledochal cyst)은 담도의 선천성 확장증(congenital dilatation of bile duct)으로 임상에서는 담도암의 전 구 병변으로 주목을 받고 있다. 담관낭종은 총담관 말단부에 서 간내 담도에 이르기까지 담도계의 어느 부위에서나 발생 할 수 있으며 서양인보다 동양인에서 더 흔하게 발생하고 남 성보다는 여성에서 호발한다. ${ }^{1}$

담관낭종이 임신과 연관된 요인 때문에 증상을 초래하는 경우는 드물다. 그러나 임신 자체에 의한 오심, 구토, 복통 등 의 생리적 증상과 구분하기가 어렵고, 임신 중 시행할 수 있는 영상검사가 제한되어 있어 담관낭종의 진단이 지연되어 ${ }^{2}$ 이 와 관련된 합병증 발생으로 산모 및 태아 모두에게 치명적인 위험을 초래할 수 있다. 담관낭종에 대한 근본적인 치료는 외 과적인 수술이나, 임신 중의 수술은 태아 및 산모 모두에서 높 은 이환율 및 사망률과 관계되므로 가능한 보존적인 치료를 시도하며 단계별 치료 전략을 세우는 것이 매우 중요하다. ${ }^{3}$

저자들은 임신 중 담관낭종에 의해 발생한 황달 및 복통으 로 내원한 26세 산모에서 투시 조영의 도움 없이 내시경 초음 파를 이용한 담도 배액술로 증상을 완화시켜 임신 기간을 연 장하였으며 성공적인 출산 후 담관낭종을 수술적으로 제거한 드문 증례를 경험하였다. 이에 임신 중 담관낭종에 대한 문헌 고찰과 함께 본 증례를 보고하는 바이다.

\section{증 례}

26세 초산부가 한달 전부터 우상복부 통증이 간헐적으로 반복되던 중, 10 일 전부터 구토 및 황달이 동반되어 연고지 산 부인과에서 복부 초음파 시행 후 본원 응급실로 내원하였다. 환자는 내원 4년 전 타원에서 촬영한 컴퓨터단층촬영(computer tomography, CT)상 담관낭종(Todani 분류 제1형)으로 진단받고 본원 소화기내과 외래로 처음 내원하였으며 당시 추 가로 시행한 영상검사에서 췌담관 합류 이상(anomalous union of pancreaticobiliary duct, AUPBD)의 동반이 의심되 었다(Fig. 1). 4년 전에 이미 수술적 절제를 권유하였으나 환자 가 증상이 없다고 수술을 원하지 않아 외래 추적관찰하였고, 임신 1년 전 마지막으로 복부 자기공명췌담도조영술(magnetic resonance cholangiopancreatography, MRCP)을 시행하였 다(Fig. 2A). 이외 과거력 및 가족력상 특이사항은 없었다.

환자는 내원 당시 임신 34 주 4 일로 우상복부 통증을 지속
적으로 호소하였으나 혈압 $139 / 90 \mathrm{mmHg}$, 체온 $36.7^{\circ} \mathrm{C}$, 맥박 91회, 호흡수 18 회로 활력징후는 안정되어 있었다. 신체 검진 상 공막 황달 소견 및 우상복부 부위에 직접 압통이 있었으나 반발 압통은 없었고, 양 하지에 함요부종이 관찰되었다.

말초 혈액 검사 소견은 백혈구 $8,900 / \mathrm{mm}^{3}$ (정상치: 4,000 $10,000 / \mathrm{mm}^{3}$ ), 혈색소 $11.3 \mathrm{~g} / \mathrm{dL}$ (정상치: $12-16 \mathrm{~g} / \mathrm{dL}$ ), 혈소판 $281,000 / \mathrm{mm}^{3}$ (정상치: $150,000-350,000 / \mathrm{mm}^{3}$ )로 경도의 빈혈 소견을 보였으며 간기능 검사상 아스파라진아미노전이효소 $49 \mathrm{IU} / \mathrm{L}$ (정상치: < $40 \mathrm{IU} / \mathrm{L}$ ), 알라닌아미노전이효소 $42 \mathrm{IU} / \mathrm{L}$ (정상치: < $40 \mathrm{IU} / \mathrm{L}$ ), 알칼리성인산분해효소 $169 \mathrm{IU} / \mathrm{L}$ (정상 치: 40-120 IU/L), 감마글루타밀전이효소 $25 \mathrm{IU} / \mathrm{L}$ (정상치: $5-36 \mathrm{IU} / \mathrm{L}$ ), 총 빌리루빈 $3.0 \mathrm{mg} / \mathrm{dL}$ (정상치: $0.2-1.2 \mathrm{mg} / \mathrm{dL}$ ), 직접 빌리루빈 $2.5 \mathrm{mg} / \mathrm{dL}$ (정상치: $<0.5 \mathrm{mg} / \mathrm{dL}$ )로 황달 소견 을 보였다. 이외 총 단백 $5.9 \mathrm{~g} / \mathrm{dL}$ (정상치: $6-8 \mathrm{~g} / \mathrm{dL}$ ), 알부민 $2.7 \mathrm{~g} / \mathrm{dL}$ (정상치: $3.5-5.2 \mathrm{~g} / \mathrm{dL}$ )로 감소되어 있었고, 아밀라아 제 $82 \mathrm{U} / \mathrm{L}$ (정상치: 30-110 U/L), 리파아제 $165 \mathrm{U} / \mathrm{L}$ (정상치: 13-60 U/L)로 리파아제의 소폭 증가 소견이 함께 관찰되었다.

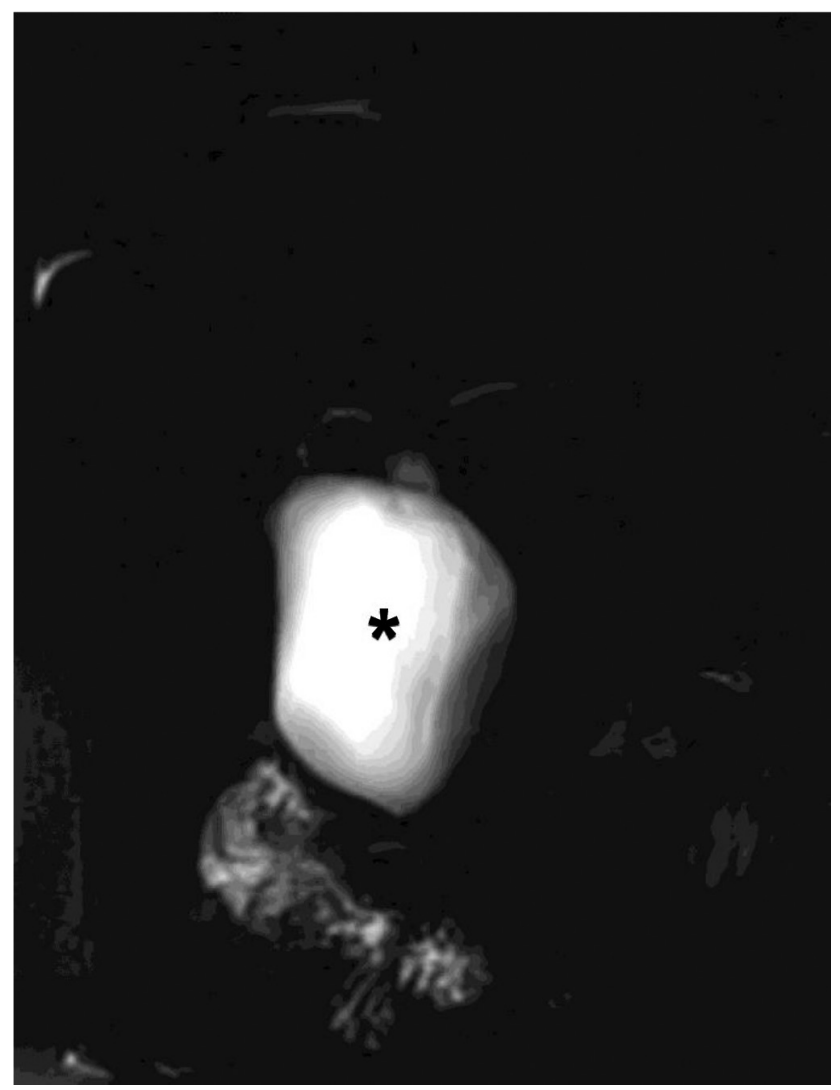

Fig. 1. Initial magnetic resonance cholangiopancreatography showed a Todani type I choledochal cyst $\left(^{*}\right)$ associated with anomalous union of pancreaticobiliary duct. 
태아 상태를 확인하기 위해 산부인과 검사를 시행하였고, 전자식 태아 심박-자궁수축 감시 장치 검사 결과 특이소견은 없었으며 질 초음파상 태아 $1.97 \mathrm{~kg}$ 으로 주수에 비해 2주 작 은 크기이나 양수량은 적당하였고, 자궁경부 길이 역시 정상 범위로 확인되었다. 환자의 복통 및 동반된 황달의 원인 감별 을 위해 $\mathrm{MRCP}$ 를 촬영하였고 간외 담도의 담관낭종이 임신 전의 최대 직경 $6 \mathrm{~cm}$ 에서 $15 \mathrm{~cm}$ 로 현저히 커진 것이 확인되 었다(Fig. 2B).

내시경 초음파 검사를 시행하였고 진정 검사를 위해 시술 직 전 프로포폴(propofol) $20 \mathrm{mg}$, 페티딘(pethidine) $25 \mathrm{mg}$ 을 정 맥 주사하였다. 검사 결과 확장된 담관낭종 내부에 다량의 슬 러지(sludge)가 관찰되었고(Fig. 3), 산모와 태아의 방사선 피
폭 없이 담관낭종을 배액하기 위해 투시 장비를 사용하지 않 고 내시경 초음파(endoscopic ultrasonography, EUS)를 이용한 담도 배액술을 진행하였다. 십이지장 구부(duodenal bulb)에서 EUS 유도 하에 19-gauge 세침(Echo-tip, Cook Medical, Bloomington, IN, USA)을 이용하여 낭종 내로 천자를 시행하 여 유도철사를 진입시키고 확장용 풍선 도관(Hurricane balloon, 4 mm, Boston Scientific Microinvasive, Boston, MA, $\mathrm{USA}$ )으로 확장을 시도하였으나 낭종 벽이 두꺼워 진입이 잘 되지 않았다. 이에 7-Fr Soehendra 스텐트 제거용 도관 (Soehendra stent retriever, Cook Medical, Bloomington, IN, $\mathrm{USA})$ 으로 트랙 확장을 시행한 후 피막형 금속 스텐트(BONASTENT, $8 \mathrm{~mm} / 6 \mathrm{~cm}$, Standard Sci Tech, Seoul, Korea)를 삽
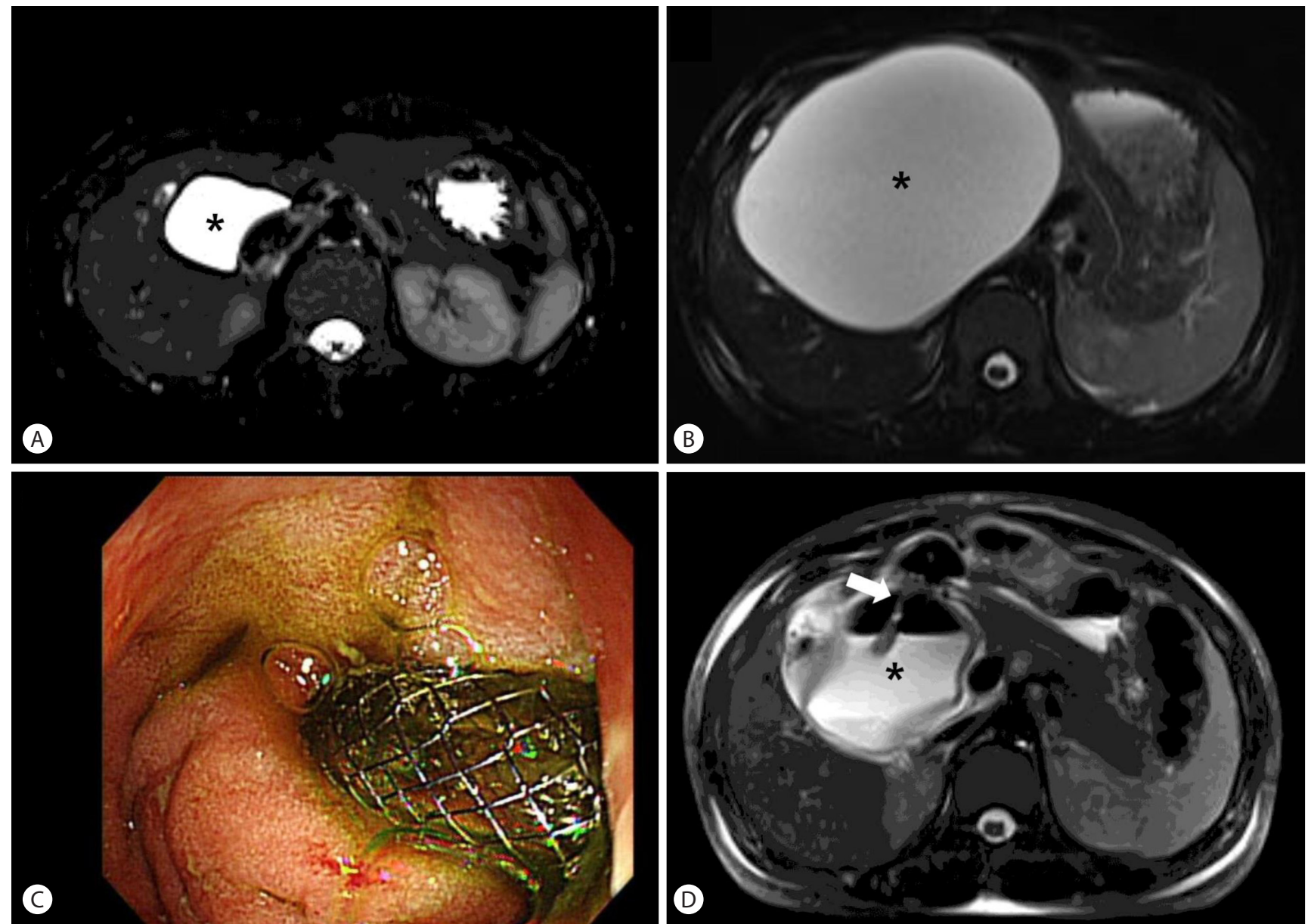

Fig. 2. Serial MRCP images of the choledochal cyst. After initially being diagnosed with choledochal cyst, the patient underwent annual follow-up MRCP. (A) About 1 year before pregnancy, the maximal size of choledochal cyst $\left({ }^{*}\right)$ was $6 \mathrm{~cm}$ with no interval change from the prior exam. (B) At 34 weeks of gestation, she presented abdominal pain with jaundice, and the size of the choledochal cyst ${ }^{*}$ ) increased to $15 \mathrm{~cm}$ in diameter. (C) Endoscopic ultrasonography-guided choledochoduodenostomy using covered metal stent was performed for biliary decompression. (D) Two days after procedure, there was a marked decrease in the size of choledochal cyst $\left(^{*}\right)$ with the choledochoduodenal stent (arrow) in situ. MRCP, magnetic resonance cholangiopancreatography. 
입하여 총담관-십이지장루 형성술(choledochoduodenostomy) 을 시행하였다(Fig. 2 C).

시술 당일부터 3세대 세팔로스포린인 세프티족심(ceftizoxime)을 시술 6시간 전부터 정맥 투여하였고, 시술 이후 환 자의 복통은 사라졌으며 간기능 수치도 정상화되었다. 이틀 뒤 촬영한 자기공명영상 검사 결과 낭종의 크기가 현저히 줄 어들었음을 확인하였다(Fig. 2D).

이후 태아의 초음파 소견상 양수 과소증을 동반한 자궁내 성장지연이 확인되어 임신 35주 5일째 제왕절개를 시행하였 고, 태아는 $2.14 \mathrm{~kg}$ 의 미숙아로 출생하였으나 호흡 및 전신상 태는 양호하였다. 환자는 충분한 산후 회복 기간을 가진 뒤, 출산 7주째 본원 외과에 입원하여 복강경하 낭종 절제술 및

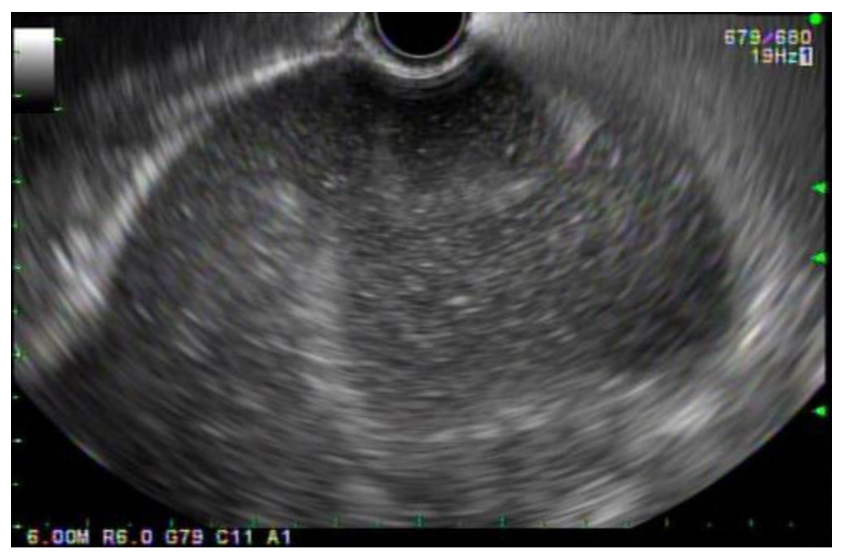

Fig. 3. Endoscopic ultrasonography (EUS) performed just prior to EUSguided choledochoduodenostomy showed large amount of echogenic debris (biliary sludge) in the enlarged choledochal cyst.
간공장문합술을 시행받았다. 수술 당시, 스텐트 삽입부 주위 로 이전 내시경 시술과 연관되었을 것으로 추정되는 염증성 유착이 낭종 주위에 관찰되었으나 수술 진행에는 어려움이 없었고 수술은 성공적이었다(Fig. 4).

\section{고 찰}

선천성 담도 확장증의 발생 원인에 대해서는 아직 뚜렷하 게 밝혀진 것은 없으나 크게 두 가지 개념으로 설명되고 있다. 첫 번째는 원시 담도의 발생 초기에 담도 상피의 불규칙적인 증식으로 인해 근위부의 상피 세포들이 원위부보다 과도하게 증식되어 근위부가 말단부보다 확장되고 약해지며, 이러한 취약성과 함께 그 말단 부위가 폐색됨으로써 낭종이 형성된 다는 발생학적인 가설이다. ${ }^{4}$ 두 번째는 '공통관 이론(common channel theory)'이다. 총담관과 주췌관이 십이지장벽 바깥에 서 합류하게 되면 긴 공통관(성인에서는 보통 $15 \mathrm{~mm}$ 이상)을 형성하게 되는데 이 경우 오디(Oddi) 괄약근의 기능이 미치지 못하고, 주췌관내 압력이 담관내 압력보다 높아 췌액이 담관 내로 지속적으로 역류하게 된다. 이로 인해 담관 상피세포의 지속적인 염증을 초래하고 담관벽의 약해져 결국 담관낭종이 발생한다는 개념이다. ${ }^{5}$

담관낭종의 합병증으로는 담석 발생으로 인한 황달, 담관 염, 췌장염, 낭종 파열 및 악성화 등이 있으며 낭종 환자의 2.5-17.5\%에서 담도암이 발생하는 것으로 보고되고 있다. 이 러한 악성화는 환자의 연령이 증가할수록 그 위험도가 증가 하는 것으로 알려져 있으며 ${ }^{6}$ 일반적인 담관낭종의 치료 원칙
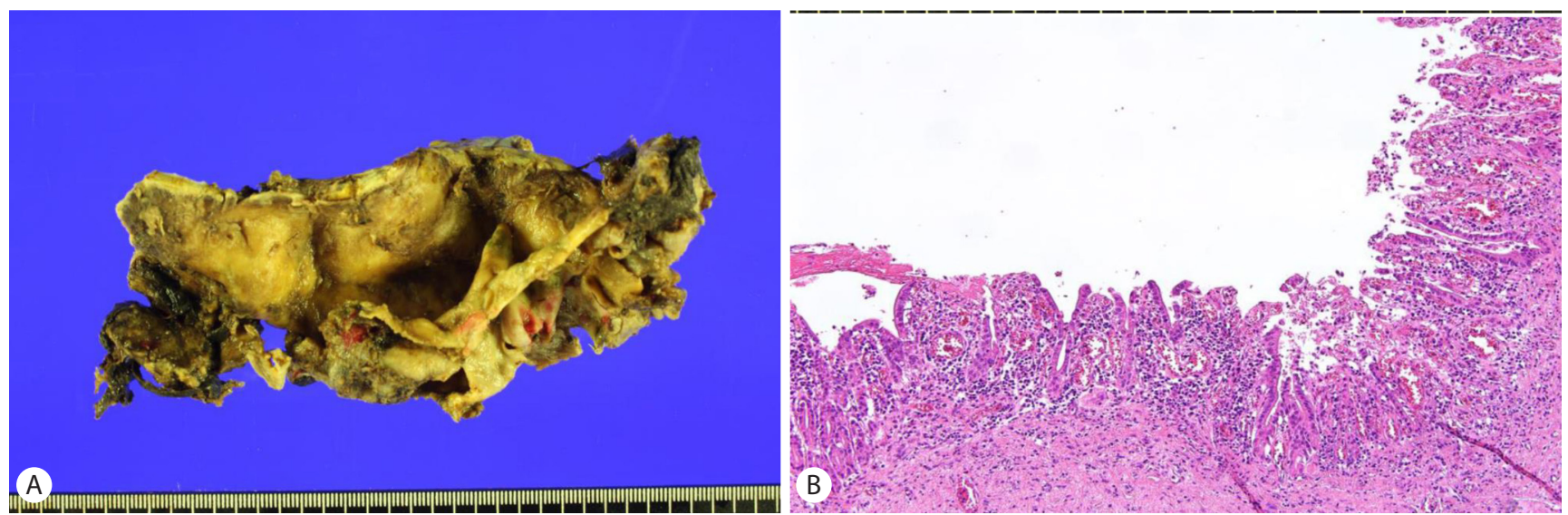

Fig. 4. At 7 weeks postpartum, laparoscopic choledochal cyst excision with hepatico-jejunostomy was done. (A) Marked cystic dilatation with wall thickening, consistent with choledochal cyst, was noted in common bile duct. Mucosal surface showed multifocal erosion and hemorrhage. (B) The mucosa showed papillary hyperplasia with erosion and moderate lymphoplasmacytic infiltration (hematoxylin and eosin, $\times 100$ ). 
은 진단되는 대로 수술적 절제를 시행하는 것이다.

임신 중 담관낭종의 증상이 발생하는 데는 여러 가지 요인 이 작용할 수 있다. 우선 내분비적인 요인으로 프로게스테론 과 에스트로겐이 관련된다. 프로게스테론은 생체 내에서 담 낭의 수축을 억제하고 에스트로겐은 담도 내로 콜레스테롤 분비를 증가시켜 담즙의 결석 형성 경향을 증가시킨다. ${ }^{7}$ 더구 나 에스트로겐은 오디 괄약근 운동성에 영향을 미쳐 담도 내 압을 증가시킨다고 알려져 있다. ${ }^{8}$ 이러한 내분비적인 요인 이 외에도 임신으로 확장된 자궁 및 증가된 복압이 담관 말단 부 위를 압박하여 임신 후반기로 가면서 담관낭종이 증상을 발 현한다는 가설이 있다. ${ }^{9}$

국내에서도 담관낭종이 임신 중 증상 및 합병증을 초래하 여 진단된 증례들이 보고되었다. 그중 임신을 유지하지 못하 고 소파술을 시행 후 담관낭종에 대한 수술을 진행한 1예, 그 리고 임신 중 담도 감압 목적으로 외과적인 총수담관 공장 문 합술을 시행한 1 예를 제외하고는 대부분의 경우 출산 시까지 보존적 치료를 받고, 출산 후 낭종절제술을 포함한 수술적 치 료를 시행받았다. ${ }^{79-11}$ 본 증례는 이러한 국내 보고들과는 달 리 이전부터 알고 있었던 담관낭종이 임신 중 증상 발현과 함 께 크기가 커지고, 확장된 담관 내부에 다량의 슬러지가 확인 된 경우로 환자는 내시경 초음파를 이용한 담도 배액술을 시 행받았다. 이전에 제시된 가설을 우리 증례에 적용하면, 임신 중 호르몬 변화로 담도내 슬러지가 형성되어 총담관 말단부 에 폐색이 발생하였고 이로 인해 담관낭종의 크기가 증가하 였을 것으로 생각된다. 내시경 초음파를 이용한 담도 감압술 이후 증상의 소실과 함께 낭종의 크기가 빠르게 감소한 점 역 시 우리 가설을 뒷받침한다고 하겠다.

총담관낭종의 비수술적 진단방법으로 복부 초음파검사, 간 담도 스캔(radionuclide scan), 복부 전산화단층촬영술, 경피 담도조영술(percutanuous transhepatic cholangiography), 내 시경적 역행성췌담도조영술(endoscopic retrograde cholangiopancreatography, ERCP) 등이 있다. 선별(screening) 목적의 초기검사로는 복부 초음파검사가 가장 유용하고, 내시경적 역행성 담도조영술은 췌담관 합류 이상의 동반 유무를 가장 정확하게 알 수 있다. ${ }^{9}$ 반면, 자기공명췌담도조영술(magnetic resonance cholangiopancreatography, $\mathrm{MRCP}$ )의 경우 방사 선 노출 없이 담관낭종의 크기와 분포 및 췌관과의 관계를 볼 수 있어 임신시 담도에 의심되는 낭종성 병변이 있을 경우 $\mathrm{ERCP}$ 를 대체할 수 있는 진단 수단이다. ${ }^{12}$ 본 증례에서도 $\mathrm{MRCP}$ 는 담관낭종의 크기 변화 및 담도 배액술의 치료 반응
평가에 매우 유용하였다.

담관낭종은 담도암의 전암성 병변이기 때문에 근본적인 치 료는 외과적 낭종절제술이다. 임신 중 우연히 발견된 담관암 이 동반되지 않은 무증상의 담관낭종은 정기적으로 복부 초 음파검사를 시행하면서 경과관찰할 수 있다. 반면에 담관낭 종이 증상을 초래하거나 낭종과 관련된 합병증이 발생한 경 우에는 빠른 치료가 요구된다. ${ }^{11}$ 본 증례에서 시행한 내시경 초음파를 이용한 낭종 감압술은 패혈증을 예방하고 통증과 황달을 완화시켜 임신을 가능하면 오래 유지시키기 위한 방 법으로 선택하였고, 개복수술로 인한 태아와 산모의 이환율 과 사망률을 고려할 때 이러한 시술은 분만 후에 시행할 근본 적인 담관낭종 절제 수술의 교량 역할을 할 수 있다. 내시경 초음파를 이용한 낭종 감압술이 실패하거나 불가능할 경우에 는 ERCP를 이용한 경유두적(transpapillary) 배액술을 고려 할 수 있다. 그러나 이 경우 투시 조영술을 이용해야 하므로 산모와 태아에 방사선 노출의 위험이 있으며 본 환자와 같이 AUPBD가 동반된 경우 경유두적 담관 배액술은 기술적으로 어려울 수 있다. 본 증례의 환자는 내시경 초음파 유도하 담 관 배액술 시행 후 건강한 태아를 출산하였고 출산 7주 후에 근본적인 낭종 절제술을 시행받았다. 일본에서도 임신 14 주 에 발견된 직경 $6 \mathrm{~cm}$ 의 담관낭종이 임신 18 주에 우리 증례와 유사하게 낭종 크기가 두 배로 증가하여 경피적 담도배액술 (percutaneous transhepatic biliary drainage, PTBD)을 시행 하였고, 이후 제왕절개술로 건강한 남아를 출산하였으며 출 산 6주 후 낭종절제술을 시행한 증례를 보고한 바 있다. ${ }^{13}$ 분 만의 방식에 대해서는 논란의 여지가 있으나 임신 말기 자궁 크기의 증가와 질식분만시 산통이 복압을 증가시켜 담관낭종 의 파열을 일으킬 가능성이 있으므로 낭종의 파열을 피하기 위해 제왕절개술을 시행하는 것이 추천된다. ${ }^{14}$

임신 중에 증상을 초래하는 담관낭종은 진단이 늦어질 경 우 다양한 합병증을 동반할 수 있기에 빠른 진단이 요구된다. 담관낭종의 근본적 치료는 외과적 절제이지만 수술로 인한 태아와 산모의 이환율 및 사망률을 고려할 때, 즉각적인 외과 수술보다는 담관낭종으로 인한 합병증을 예방하고 출산 시 까지 산모와 태아를 안전하게 보호하기 위한 단계적인 치료 전략이 중요하다. 본 증례는 임신과 연관되어 담관낭종이 증 상을 초래한 것으로 추정되며, 투시 조영 도움 없이 내시경 초 음파 담도 배액술로 증상을 완화시키고 건강한 출산 후에 담 관낭종을 수술적으로 절제한 증례로서, 발달된 영상 진단법 과 내시경 시술 기법 등을 통해 향후 담관낭종으로 내원한 산 
모의 경과에 좋은 예후를 기대할 수 있을 것으로 사료된다.

\section{요 약}

담관낭종은 담도가 비가역적으로 확장된 선천성 질환으로 담도암의 발생 위험으로 인해 수술적 절제를 시행하는 것이 원칙이다. 임신 중에는 호르몬의 영향 및 확대된 자궁, 증가된 복압 등으로 담관낭종이 증상을 일으킬 수 있다. 그러나 임신 중에는 생리적 변화로 나타나는 임신 자체의 증상과 낭종에 의한 증상을 구분하기가 어렵고, 임신 중 시행할 수 있는 영상 검사가 제한되어 있어 담관낭종의 진단이 지연됨으로써 산모 와 태아에게 치명적인 결과를 초래할 수 있다. 또한 수술로 인 한 태아와 산모의 이환율과 사망률을 고려할 때, 즉각적인 외 과 수술보다는 담관낭종으로 인한 합병증을 예방하고 출산 시까지 산모와 태아를 안전하게 보호하기 위한 단계적인 치료 전략이 중요하다. 저자들은 임신 중 담관낭종에 의해 발생한 황달 및 복통으로 내원한 26세 산모에서 투시 조영술 도움 없 이 내시경 초음파를 이용한 담도 배액술을 시행하여 증상 완 화와 함께 최대한 임신을 유지할 수 있었다. 이후 성공적인 출 산 및 산후 회복기를 거쳐 담관낭종을 수술적으로 제거한 1 예 를 경험하였기에 문헌고찰과 함께 보고하고자 한다.

국문 색인: 담관낭종, 임신, 내시경 초음파, 총담관-십이지 장루 형성술

\section{Conflicts of Interest}

The author has no conflicts to disclose.

\section{REFERENCES}

1. Cho YH, Jeon TY, Kim HY, Sim MS. Clinical analysis of choledochal cyst. Korean J Hepatobiliary Pancreat Surg 1999;3:39-47.

2. Aszodi A, Ponsky JL, Kiwi R, Parulekar SG. Choledochal cyst in a pregnant adult. Am J Gastroenterol 1990;85:1048-1049.

3. Gmijović D, Stojanović M, Radojković M, Jeremić L, Širić Z. Complicated choledochal cysts in pregnancy. Facta Univ Ser Med Biol 2006;13:90-93.

4. Elgar $\mathrm{DE}$, Gudgeon $\mathrm{DH}$. Choledochus cyst complicating pregnancy. $\mathrm{Br}$ J Surg 1969;56:868-870.

5. Todani T, Watanabe Y, Fujii T, Uemura S. Anomalous arrangement of the pancreatobiliary ductal system in patients with a choledochal cyst. Am J Surg 1984;147:672-676.

6. Voyles CR, Smadja C, Shands WC, Blumgart LH. Carcinoma in choledochal cysts. Age-related incidence. Arch Surg 1983;118:986-988.

7. Yi SY, Jung HK, Son HY, et al. A case of rupture of choledochal cyst during pregnancy. Korean J Gastroenterol 2000;35:263-267.

8. Tierney S, Qian Z, Burrow C, Lipsett PA, Pitt HA, Lillemoe KD. Estrogen inhibits sphincter of Oddi motility. J Surg Res 1994;57:69-73.

9. Nam SY, Kim MJ, Park IY, et al. A case of choledochal cyst diagnosed and conservatively treated during pregnancy. Korean J Obstet Gynecol 2008:51:1499-1503.

10. Son HJ, Paik SW, Rhee PL, Kim JJ, Koh KC, Rhee JC. Acute pancreatitis complicating pregnancy in a patient with co-existing choledochal cyst. Korean J Intern Med 1997;12:105-108.

11. Moon JS, Kang HK, Lee BH. Choledochal cysts aggravated during pregnancy. J Korean Surg Soc 1997;52:371-378.

12. Shanley DJ, Gagliardi JA, Daum-Kowalski R. Choledochal cyst complicating pregnancy: antepartum diagnosis with MRI. Abdom Imaging 1994:19:61-63.

13. Nasu K, Matsuki S, Kawano Y, Miyakawa I, Nakashima K, Anai H. Choledochal cyst diagnosed and conservatively treated during pregnancy. Am J Perinatol 2004;21:463-468.

14. Binstock M, Sondak VK, Herd J, et al. Adenocarcinoma in a choledochal cyst during pregnancy: a case report and guidelines for management. Surgery 1988;103:588-592. 